\title{
Using the K/BxN mouse model of endogenous, chronic, rheumatoid arthritis for the evaluation of potential immunoglobulin-based therapeutic agents, including IVlg and Fc- $\mu$ TP-L309C, a recombinant lgG1 Fc hexamer
}

Bonnie J. B. Lewis ${ }^{1,2}$, Jade Ville ${ }^{2,3}$, Megan Blacquiere ${ }^{2}$, Selena Cen ${ }^{2}$, Rolf Spirig ${ }^{4}$, Adrian W. Zuercher ${ }^{4}$, Fabian Käsermann ${ }^{4}$ and Donald R. Branch ${ }^{1,2,5^{*}}$ (D)

\begin{abstract}
Background: High-dose intravenous immunoglobulin (IVlg), and more recently, subcutaneously-delivered lg (SClg), are used to treat a variety of autoimmune diseases; however, there are challenges associated with product production, availability, access and efficacy. These challenges have provided incentives to develop a human recombinant FC as a more potent alternative to IVlg and SClg for the treatment of autoimmune diseases. Recently, a recombinant human IgG1 FC hexamer (FC- $\mu$ TP-L309C) was shown to be more efficacious than IVIg in a variety of autoimmune mouse models. We have now examined its efficacy compared to IVlg and SClg in the K/BxN mouse model of endogenous, chronic rheumatoid arthritis (RA).

Result: Using the serum-transfer K/BxN model and the endogenous autoimmune model, amelioration of the arthritis was achieved. Effective treatment required high and frequent doses of IVIg, SClg and FC- $\mu$ TP-L309C. However, FC- $\mu$ TP-L309C was efficacious at 10-fold lower doses that IVlg/SClg. Also, arthritis could be prevented when FC- $\mu$ TP-L309C was given prior to onset of the arthritis in both the endogenous model and in the serum transfer model.
\end{abstract}

Conclusions: Our results show that FC- $\mu$ TP-L309C is a powerful treatment for the prevention and amelioration of severe, chronic arthritis in a true autoimmune mouse model of RA. Thus, the K/BxN endogenous arthritis model should be useful for testing potential therapeutics for RA. Our findings provide rationale for further examination of the treatment efficacy of immunoglobulin-based therapeutics in rheumatoid arthritis.

Keywords: Recombinant Fc hexamer, Fc- $\mu$ TP-L309C, Intravenous immunoglobulin, IVIg, Subcutaneous immunoglobulin, SClg, Rheumatoid arthritis, RA, Autoimmune disease

\footnotetext{
* Correspondence: don.branch@utoronto.ca

'Department of Laboratory Medicine and Pathobiology, University of

Toronto, 67 College St., Toronto, Ontario M5G 2M1, Canada

${ }^{2}$ Centre for Innovation, Canadian Blood Services, 67 College St., Toronto,

Ontario M5G 2M1, Canada

Full list of author information is available at the end of the article
}

(c) The Author(s). 2019 Open Access This article is distributed under the terms of the Creative Commons Attribution 4.0 International License (http://creativecommons.org/licenses/by/4.0/), which permits unrestricted use, distribution, and

reproduction in any medium, provided you give appropriate credit to the original author(s) and the source, provide a link to the Creative Commons license, and indicate if changes were made. The Creative Commons Public Domain Dedication waiver (http://creativecommons.org/publicdomain/zero/1.0/) applies to the data made available in this article, unless otherwise stated. 


\section{Background}

Plasma derived IgG is a major replacement therapy for primary immunodeficiency [1-3] and is a first line treatment for diseases such as immune thrombocytopenia (ITP) [4-9], chronic inflammatory demyelinating polyneuropathy (CIDP) [10] and Kawasaki disease $[11,12]$. Additionally, it is used to treat a variety of other autoimmune and inflammatory diseases and neurologic disorders in combination with other therapies or when traditional therapies fail [13-21]. Although both $\mathrm{F}\left(\mathrm{ab}^{\prime}\right)_{2^{-}}$and $\mathrm{Fc}$-dependent mechanisms have been suggested to be involved in the anti-inflammatory effects of this therapy, research in the field has emphasized that the IgG Fc fragment is crucial for its immunomodulatory properties [22]. Some of the proposed Fc-dependent mechanisms include the blockade of activating $\mathrm{Fc} \gamma$ receptors (Fc $\gamma \mathrm{Rs})$ [23], the requirement for the neonatal Fc receptor $(\mathrm{FcRn})[24,25]$, the expansion of regulatory $\mathrm{T}$ cell populations [26], the upregulation of the inhibitory receptor FcyRIIB [27] and the modulation of dendritic cell activity $[28,29]$.

Today, plasma derived IgG is pooled from the blood of thousands of donors and manufactured via chromatographic processes to formulate a highly purified, polyclonal IgG product that is suitable for i.v. (intravenous immunoglobulin, IVIg) or s.c. (subcutaneous immunoglobulin, SCIg) applications [30, 31]. Even though the use of SCIg has increased the patient convenience associated with IVIg treatment, its manufacture still requires highly specialized production facilities with a focus on pathogen safety [31, 32]. Moreover, its supply is dependent on the availability and the collection of human plasma and it is subject to some natural variability. These challenges associated with growing product demand, production and availability have provided incentives to develop various Fc constructs as potential alternatives to IVIg/SCIg for diseases where its mechanism has been suggested to be Fc-dependent [22-29].

Various Fc multimers have been produced that show enhanced efficacy compared to IVIg for amelioration of disease in animal models, such as ITP and arthritis [3341]. In a recently published paper, we reported a recombinant human IgG1 Fc, Fc- $\mu$ TP-L309C, which was produced by fusing the 18 aa IgM tail-piece to the $\mathrm{C}$ terminus of a variant human IgG1 Fc with a point mutation at position 309 [38]. This point mutation facilitates the stabilized hexamerization of this molecule through the formation of disulphide bonds and distinguishes this recombinant hexamer from others reported [38]. We showed that Fc- $\mu$ TP-L309C has high binding avidity for Fc receptors and could suppress acute collagen antibody- and chronic collagen-induced arthritis and ameliorate ITP in mouse models when given therapeutically at 10-fold lower doses than IVIg [38].
With the limited amount of studies performed on the therapeutic efficacy of IVIg in rheumatoid arthritis (RA) [20, 42-47], we decided to examine whether IVIg could ameliorate arthritis in an endogenous, chronic mouse model of RA. The $\mathrm{K} / \mathrm{BxN}$ serum-transfer model is an established mouse model of RA that recapitulates the effector phase of the disease and has been examined for potential treatment efficacy of IVIg by a number of investigators [48-51]. However, $\mathrm{K} / \mathrm{BxN}$ mice, themselves, that spontaneously generate a true autoimmunemediated RA, have never been used as a therapeutic tool to investigate the efficacy of RA therapeutic agents, including IVIg.

$\mathrm{K} / \mathrm{BxN}$ mice are generated using KRN mice expressing a T-cell receptor (TCR) transgene for glucose-6phosphate isomerase (G6PI) peptide in the context of IAg7 MHC II [52]. To generate $\mathrm{K} / \mathrm{BxN}$ mice, KRN are bred with NOD/Lt mice expressing the MHC II haplotype IAg7 that is required to interact with the TCR transgene. This mating results in the generation of a true autoantibody to G6PI [52-55]. G6PI is present on the articular cartilage and thus, immune complexes form to drive the activation of various immune cells [52-55]. Since the sera of $\mathrm{K} / \mathrm{BxN}$ mice contain pathogenic autoantibodies to G6PI, it can be transferred into naïve mice and arthritic manifestations occur a few days to weeks later [48-51]. However, serum recipients develop arthritis in the absence of the adaptive immune system, which poses serious limitations for examining the intricacies of the human disease. Thus, instead of a serumtransfer model, we used the endogenous $\mathrm{K} / \mathrm{BxN}$ mice to better recapitulate the autoimmune-mediated RA; the resulting immune-mediated mechanism would include the influence of T-cells, antigen presenting cells and Bcells; a true autoimmune condition. Because no one has previously shown that IVIg could ameliorate the endogenous chronic arthritis in this mouse model, we used a dose escalation and frequency of dosing approach to determine if IVIg had any efficacy in this RA model. We also investigated the therapeutic efficacy of SCIg and Fc$\mu$ TP-L309C in this same model to determine efficacy, if any, and whether any of these agents could serve as a potential therapeutic alternative for the treatment of RA.

\section{Results}

\section{IVlg can treat chronic inflammatory arthritis}

It is controversial as to whether IVIg can be used in the treatment of RA; although, only low doses, not immunomodulatory doses, have been examined [20, 42-47]. Previously, in mouse models of collagen-induced arthritis, we showed that Fc- $\mu$ TP-L309C could ameliorate the arthritis using a 10-fold lower dose than IVIg [38]. However, the $\mathrm{K} / \mathrm{BxN}$ mouse model is a very robust chronic arthritis model and is considered to be a better model of 
human rheumatoid arthritis [52-58]; thus, we wanted to test efficacy of IVIg, SCIg and Fc- $\mu$ TP-L309C in this endogenous, chronic mouse model of RA and evaluate whether this particular mouse model could be useful to evaluate future potential treatments for RA.

We first used a dose-escalation and frequency of dosing approach to determine if there was any effect on endogenous RA and, if so, an optimal dose and dosing schedule at which IVIg exhibited therapeutic efficacy in the treatment of arthritis in $\mathrm{K} / \mathrm{BxN}$ mice. First, we determined whether there was an optimal dosing of IVIg that would reduce the clinical scores and paw swelling of K/ BxN mice with chronic arthritis. We administered 6 treatments with IVIg given i.p. at doses of $1 \mathrm{~g} / \mathrm{kg}, 2 \mathrm{~g} / \mathrm{kg}$ and $4 \mathrm{~g} / \mathrm{kg}$ over the course of this experiment. Treatments were administered on days $1,3,5,7,9$, and 11 . Clinical scores and hind paw widths of the mice were monitored and it was shown that the clinical scores and paw widths of the mice treated with multiple doses of 4 and $2 \mathrm{~g} / \mathrm{kg}$ of IVIg (Fig. 1a \& b) were significantly reduced in comparison to mice that were given the same $\mathrm{g} / \mathrm{kg}$ dose of HSA. However, the clinical scores and paw widths of mice that were treated with multiple doses of $1 \mathrm{~g} / \mathrm{kg}$ of IVIg (Fig. 1a \& b) were not reduced in comparison to mice that were given the same $\mathrm{g} / \mathrm{kg}$ dose of HSA. Further modifying the dosing regimen was not optimal as the mice tended to rebound with their arthritis with reducing or stopping the dosing (data not shown).

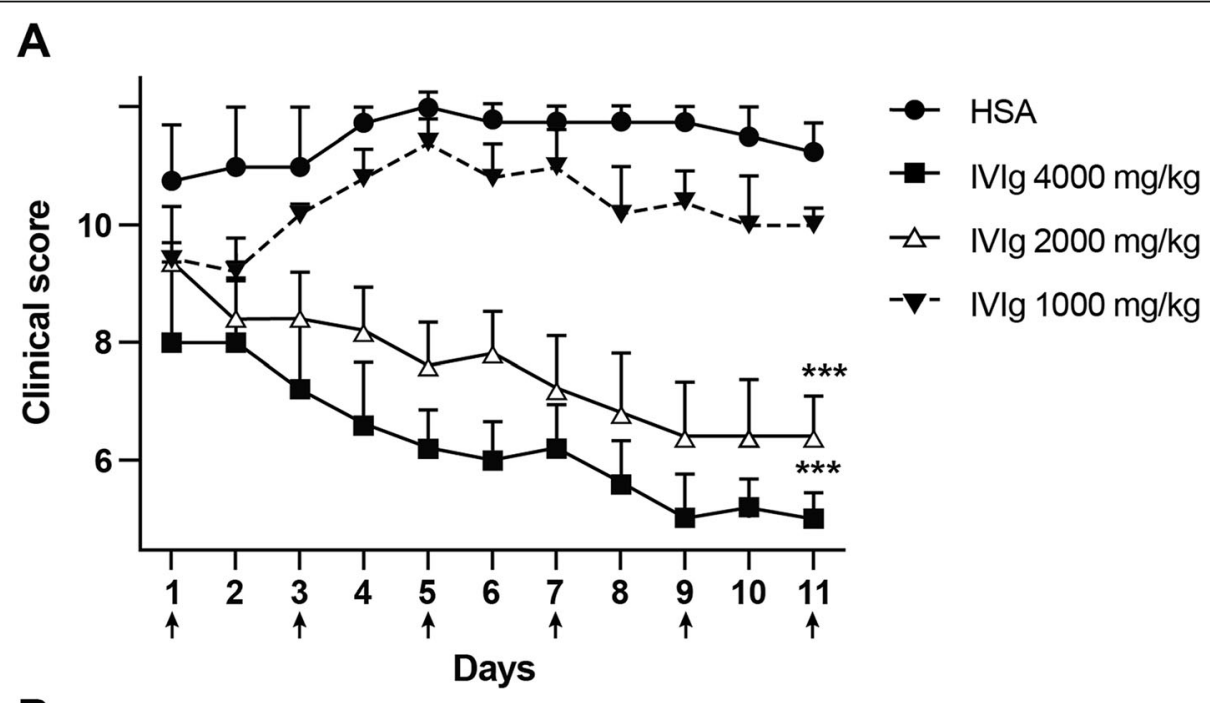

B

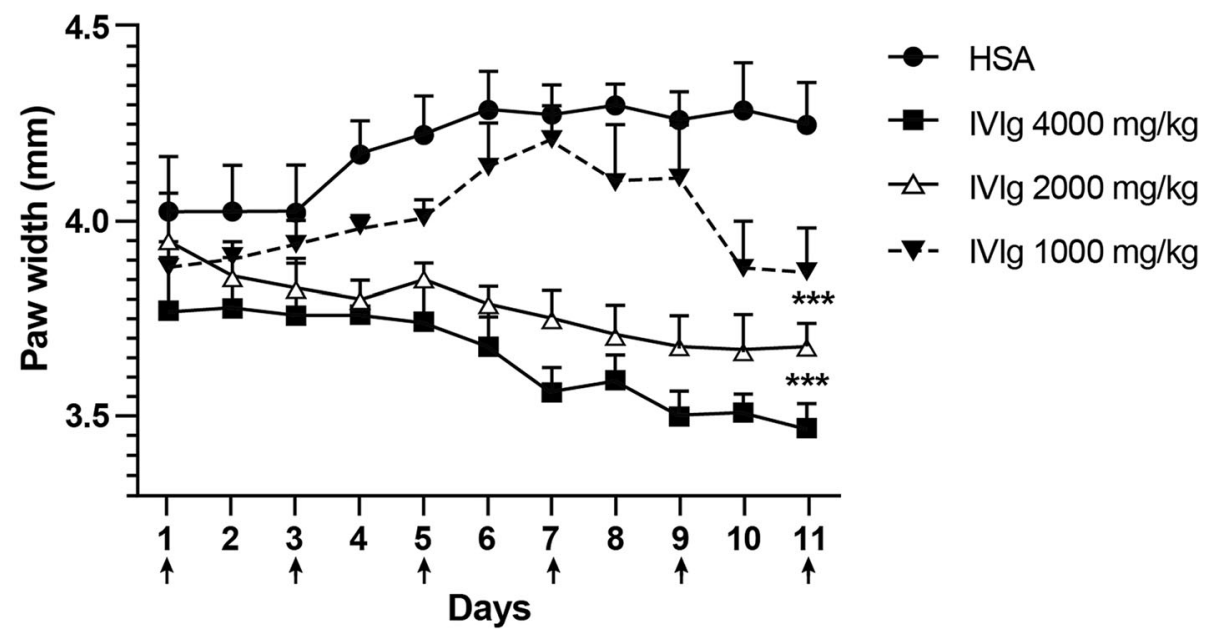

Fig. $1 \mathrm{IVlg}$ treats chronic inflammatory arthritis optimally at $2 \mathrm{~g} / \mathrm{kg}$ doses, administered every other day. The clinical scores (a) and paw width measurements (b) are shown for mice treated with multiple doses of $4 \mathrm{~g} / \mathrm{kg}, 2 \mathrm{~g} / \mathrm{kg}$ or $1 \mathrm{~g} / \mathrm{kg}$ of IVlg, using HSA-treated mice as a control. Arrows indicate treatment given on days 1, 3, 5, 7, 9, and 11. Shown are the average clinical scores and the average paw width measurements (mm); error bars indicate range of clinical scores/range of paw widths (mean $\pm S D ; n=4-5$ for each treatment group). ${ }^{* *} P<0.0014 \mathrm{~g} / \mathrm{kg}$ vs. HSA and 2 $\mathrm{g} / \mathrm{kg}$ IVlg vs. HSA 
As the dosing with $2 \mathrm{~g} / \mathrm{kg}$ or $4 \mathrm{~g} / \mathrm{kg}$ gave similar amelioration of the arthritis, we decided that an optimal dose of IVIg could be administered using $2 \mathrm{~g} / \mathrm{kg}$ every other day.

\section{FC- $\mu$ TP-L309C is more efficacious than IVlg at treating} chronic arthritis

After demonstrating that IVIg could effectively ameliorate chronic arthritis at $2 \mathrm{~g} / \mathrm{kg}$ with doses administered every other day, we next wanted to investigate whether SCIg and Fc- $\mu$ TP-L309C could do the same or better. We administered 6 s.c. treatments of SCIg at $2 \mathrm{~g} / \mathrm{kg}$ or 6 s.c. treatments of Fc- $\mu$ TP-L309C at 200 $\mathrm{mg} / \mathrm{kg}, 100 \mathrm{mg} / \mathrm{kg}$ or $50 \mathrm{mg} / \mathrm{kg}$ over the course of this experiment. We started with a dose of $200 \mathrm{mg} / \mathrm{kg}$ for Fc- $\mu$ TP-L309C because of our previous work showing this to be an optimal dose for amelioration of ITP and collagen-induced arthritis [38].
Treatments were administered on days $1,3,5,7,9$, and 11 . We monitored the clinical scores and hind paw widths of the mice and found that the clinical scores and paw widths of the mice treated with multiple doses of 2 $\mathrm{g} / \mathrm{kg}$ of SCIg (Fig. 2a \& b) were reduced in comparison to mice that were given the same $\mathrm{g} / \mathrm{kg}$ dose of HSA. However, we also found that the clinical scores and the paw widths of mice treated with multiple doses of 200 $\mathrm{mg} / \mathrm{kg}$ of Fc- $\mu$ TP-L309C (Fig. 2a \& b) were significantly reduced in comparison to mice that were given $2 \mathrm{~g} / \mathrm{kg}$ SCIg or the same $\mathrm{g} / \mathrm{kg}$ dose of HSA. Fc- $\mu$ TP-L309C exhibited a dose-response as even doses of $50 \mathrm{mg} / \mathrm{kg}$ and $100 \mathrm{mg} / \mathrm{kg}$ showed a trend for efficacy with $200 \mathrm{mg} / \mathrm{kg}$ being the most efficacious. Even though SCIg could ameliorate arthritis with the same dosing scheme as IVIg, Fc- $\mu$ TP-L309C exhibited greater therapeutic efficacy than both IVIg and SCIg in this model at 10-fold lower doses.

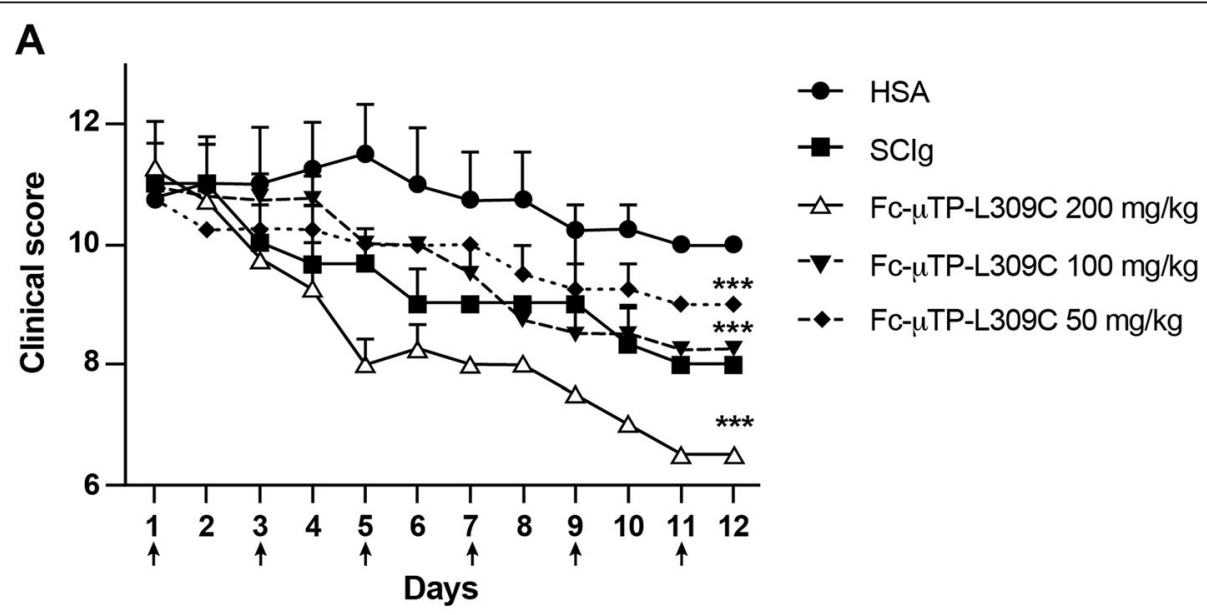

B

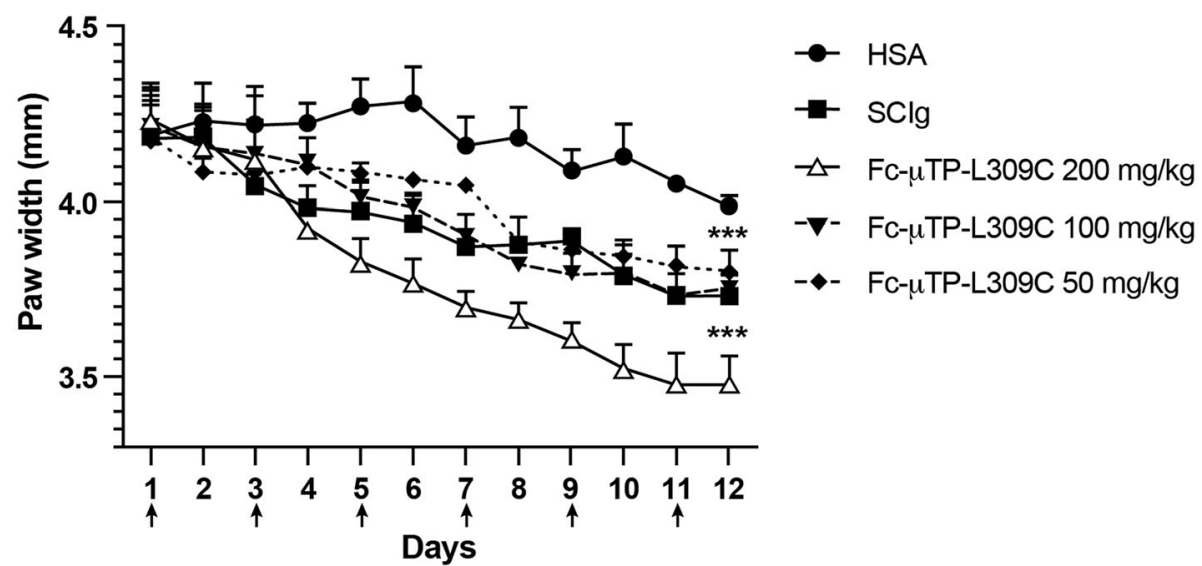

Fig. 2 Therapeutic effect of FC- $\mu$ TP-L309C in experimental arthritis. The clinical scores (a) and paw width measurements (b) are shown for mice treated with multiple doses of $2 \mathrm{~g} / \mathrm{kg}$ of SClg or with multiple doses of $200 \mathrm{mg} / \mathrm{kg}, 100 \mathrm{mg} / \mathrm{kg}$, or $50 \mathrm{mg} / \mathrm{kg}$ of FC- $\mu$ TP-L309C, using HSA-treated mice as a control. Injections were given on days 1, 3, 5, 7, 9, and 11. Shown are the average clinical scores and the average paw width measurements $(\mathrm{mm})$; error bars indicate range of clinical scores/range of paw widths (mean \pm SD; $n=5$ for each treatment group). ${ }^{* * *} P<0.0001$ 200 mg/kg Fc- $\mu$ TP-L309C vs. 2000 mg/kg SClg 
Fc- $\mu$ TP-L309C, IVlg and SClg can prevent arthritis in both the endogenous and in the serum transfer $\mathrm{K} / \mathrm{BxN}$ model As a complimentary study to our investigation of the therapeutic efficacy of IVIg, SCIg and Fc- $\mu$ TP-L309C in the $\mathrm{K} / \mathrm{BxN}$ model, we wanted to investigate whether these immunoglobulin-based agents could also prevent arthritis. The first approach we used to examine this was to treat 21-day old $\mathrm{K} / \mathrm{BxN}$ mice with either 11 i.p. injections of $2 \mathrm{~g} / \mathrm{kg}$ of IVIg or s.c. injections of SCIg or 11 s.c. injections of $200 \mathrm{mg} / \mathrm{kg}$ of Fc- $\mu$ TP-L309C. The clinical scores of the mice were monitored over the course of this experiment. Injections were administered on days 1 ,
$3,5,7,9,11,13,15,17,19$, and 21 . We found that the clinical scores did not significantly increase in mice treated with $2 \mathrm{~g} / \mathrm{kg}$ of IVIg (Fig. 3a) or SCIg (Fig. 3a) or with $200 \mathrm{mg} / \mathrm{kg}$ of Fc- $\mu$ TP-L309C (Fig. 3a) in comparison to mice treated with HSA. However, the increase in clinical scores of mice treated with IVIg/SCIg were higher than the increase in clinical scores of mice treated with Fc- $\mu$ TP-L309C. Prophylaxis using SCIg appeared to not be as efficacious as either IVIg or Fc- $\mu$ TP-L309C early on; however, severe arthritis was prevented. Importantly, prophylactic treatment using Fc- $\mu$ TP-L309C appeared to completely prevent onset of arthritis,

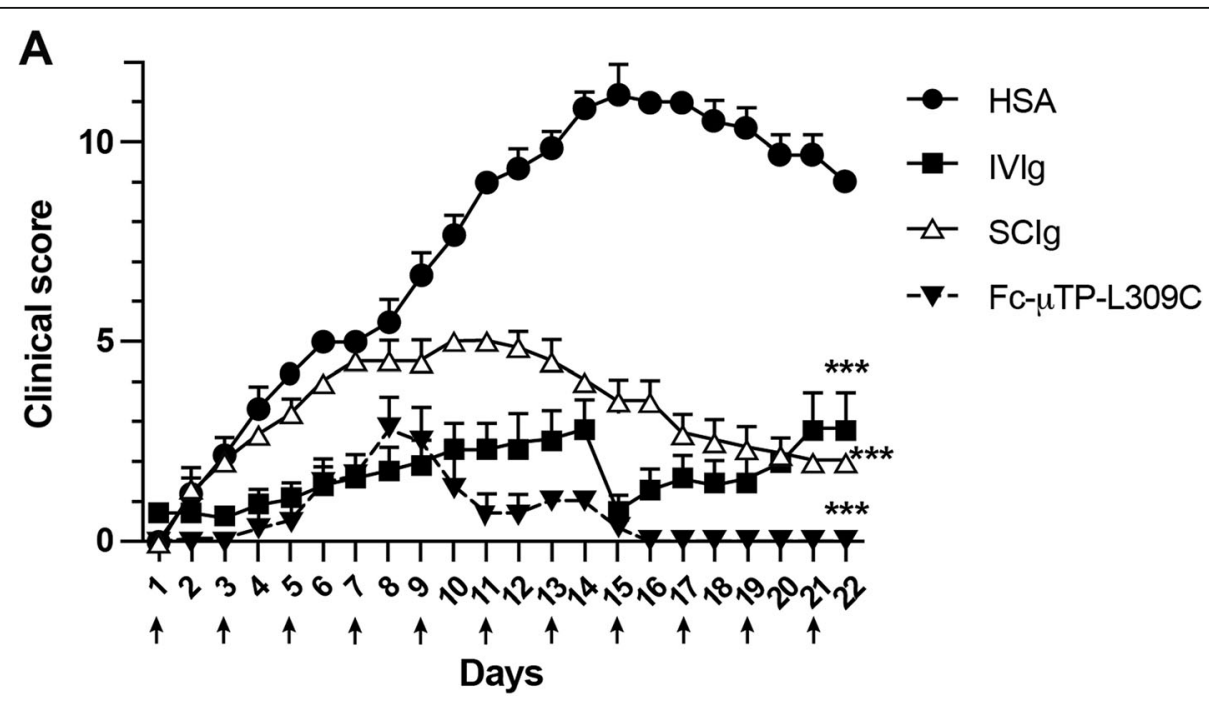

B
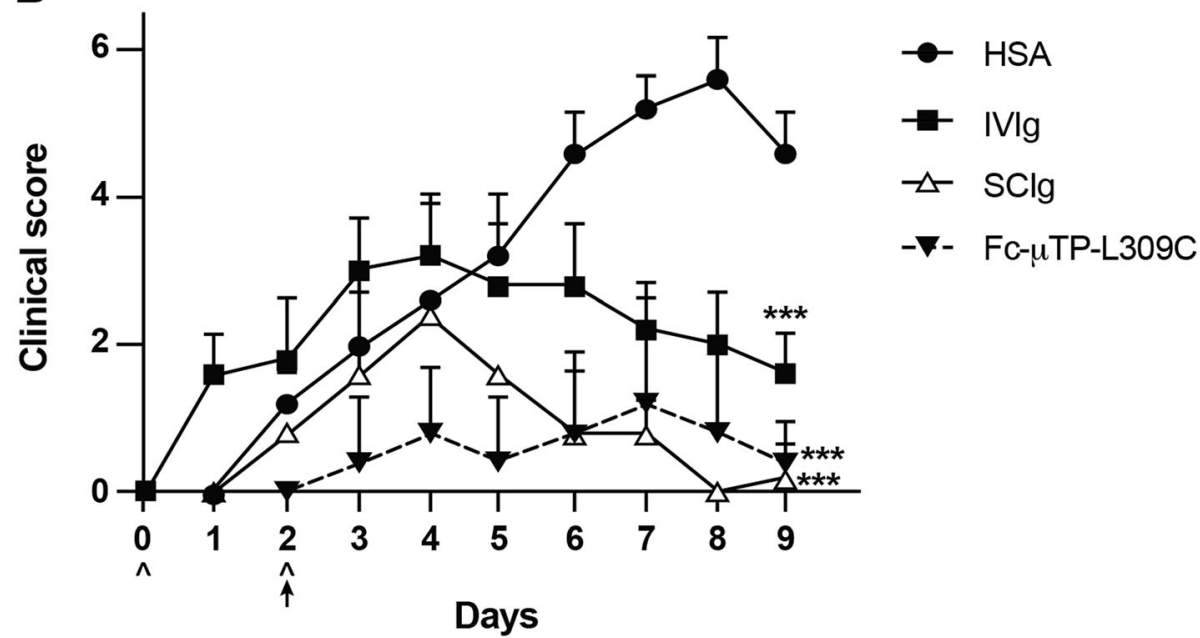

Fig. 3 FC- $\mu$ TP-L309C, IVlg and SClg can prevent arthritis in both the endogenous and in the serum transfer model. The clinical scores (a) are shown for mice treated with 11 injections of IVIg, SClg or FC- $\mu$ TP-L309C. Injections were given on days 1, 3, 5, 7, 9, 11, 13, 15, 17, 19 , and 21. Shown are the average clinical scores; error bars indicate range of clinical scores (mean \pm SD; $n=6$ for each treatment group). ${ }^{* * *} P<0.00012000$ $\mathrm{mg} / \mathrm{kg}$ IVlg vs. HSA, $2000 \mathrm{mg} / \mathrm{kg}$ SClg vs. HSA and $200 \mathrm{mg} / \mathrm{kg}$ Fc- $\mu$ TP-L309C vs. HSA. Similar results were obtained in two independent experiments. The clinical scores (b) are shown for BALB/C mice given i.p. injections of $200 \mu$ lof arthritic serum on days 0 and 2, indicated by $\wedge$, that were treated with $2 \mathrm{~g} / \mathrm{kg}$ of IVlg or SClg or with $200 \mathrm{mg} / \mathrm{kg}$ of FC- $\mu$ TP-L309C on day 2, indicated by arrow, in comparison to mice treated with HSA. Shown are the average clinical scores; error bars indicate range of clinical scores (mean \pm SD; $n=5$ for each treatment group). ***P $<$ $0.00012000 \mathrm{mg} / \mathrm{kg}$ IVlg vs. HSA, $2000 \mathrm{mg} / \mathrm{kg}$ SClg vs. HSA and $200 \mathrm{mg} / \mathrm{kg}$ Fc- $\mu$ TP-L309C vs. HSA 
bringing clinical scores to baseline levels. This again highlights the therapeutic efficacy of Fc- $\mu$ TP-L309C over IVIg and SCIg.

The second approach we used was to examine the prophylactic effect of these immunoglobulin-based agents on the severity of $\mathrm{K} / \mathrm{BxN}$ serum transfer-induced arthritis. We used Balb/c mice for these experiments treated with IVIg, SCIg and Fc- $\mu$ TP-L309C. Similar results were found in this model as in the endogenous model (Fig. 3b). However, in this model IVIg appeared to be less able to provide prophylaxis early on but all agents resulted in the inhibition of progression of the arthritis by day $9-10$.

\section{Discussion}

The value of IVIg in the treatment of RA has not been extensively evaluated. The human trials that have been done to evaluate this were small and not well controlled, and the results were equivocal [20,42-47]. The patient cohorts for these studies were small, with some studies having less than 20 patients enrolled [42, 43]. A highdose IVIg protocol of $1-2 \mathrm{~g} / \mathrm{kg}$ of IVIg per month for a minimum of 6 months is critical for effectively treating systemic autoimmune diseases [59]. However, these aforementioned studies used lower than immunomodulatory doses of IVIg, used different doses and dosing schedules without any consistent long-term follow-up [42-47]. In mouse models of RA, only collagen-induced and serum-transfer models have been used to evaluate therapeutic efficacy of immunoglobulin-based agents $[38,60,61]$. Given the lack of understanding we have about the therapeutic efficacy of IVIg in RA, we wanted to determine if the $\mathrm{K} / \mathrm{BxN}$ mouse model of endogenous, chronic rheumatoid arthritis could be used to evaluate potential therapeutic treatments.

We first investigated whether IVIg could treat autoimmune-mediated arthritis in the $\mathrm{K} / \mathrm{BxN}$ mouse model [56-58]. Other researchers have used the $\mathrm{K} / \mathrm{BxN}$ serum transfer model to study arthritis whereby the inflammatory response in the serum recipients happens in the absence of the adaptive immune system [48-51]. Although this model is a useful tool to understand how autoantibodies drive the progression of arthritis by interacting with downstream components of the innate immune system, there are some major differences between the serum transfer model and the human disease. These include differences in antibody specificities and function, and differences in immune cells that drive pathogenesis $[53,55]$. Considering this, we decided to treat $\mathrm{K} / \mathrm{BxN}$ mice with severe arthritis endogenously because we, and others, believe that the immune cells involved in driving the inflammatory response in $\mathrm{K} / \mathrm{BxN}$ mice more tightly mimic those experienced in the human seropositive disease $[52,57,58]$.
We are the first to use immunoglobulin-based agents to try and treat the spontaneous generation of RA in the $\mathrm{K} / \mathrm{BxN}$ mouse model. Therefore, we first used a multiple dose and frequency of dosing approach to determine if there was any effect on the RA and, if so, the optimal treatment regimen where IVIg was effective. We used an established clinical scoring system to determine when the mice had reached a high level of arthritis, which resulted in a clinical score of 10-12 per mouse. Upon reaching a high clinical score, we then treated these mice with $4 \mathrm{~g} / \mathrm{kg}, 2 \mathrm{~g} / \mathrm{kg}$ and $1 \mathrm{~g} / \mathrm{kg}$ of IVIg, 2 times per week. With this dosing scheme, we did not observe any decrease in clinical scores or amelioration of arthritis (data not shown). Next, we treated these mice with the same doses of IVIg, administered every other day. With this dosing scheme, we found that the mice that were given $2 \mathrm{~g} / \mathrm{kg}$ and $4 \mathrm{~g} / \mathrm{kg}$ doses showed a similar, significant decrease in their clinical scores and in their paw measurements in comparison to mice given HSA. This is something that has not been shown before in this mouse model of arthritis, however it is comparable to results found in the $\mathrm{K} / \mathrm{BxN}$ serum-transfer model $[40,50]$ and in the more commonly known arthritis models such as the collagen-antibody-induced arthritis (CAIA) and the collagen-induced arthritis (CIA) models [38], demonstrating the efficacy of IVIg in mouse models of arthritis $[38,48,49,51,62,63]$.

Upon establishing the efficacy of IVIg in the $\mathrm{K} / \mathrm{BxN}$ mouse model, we wanted to compare its effects with those of Fc- $\mu$ TP-L309C and SCIg. Both i.v. and i.p. injection of IVIg have been used previously without any evidence of a difference in efficacy. Because i.p. is easier and more volume can be injected, we used i.p.in our studies. We observed that SCIg and IVIg were equally effective at ameliorating endogenous arthritis and that Fc- $\mu$ TP-L309C was more effective than both SCIg and IVIg at 10-fold lower doses. It should be noted that Fc$\mu$ TP-L309C also exhibited higher therapeutic efficacy when given intraperitoneally in both the CIA and in the CAIA mouse models of arthritis [38]. In our case, to better insure we would see an effect, we used high doses of Fc- $\mu$ TP-L309C, due to the higher frequency of dosing, and was based on the serum half-life of Fc- $\mu$ TP-L309C to be very short [38]. Additionally, it has been proposed that subcutaneous absorption of biotherapeutics is relatively slow and mostly incomplete [64]. These factors also pose potential issues in developing dosing schemes to test the efficacy of Fc- $\mu$ TP-L309C to treat human diseases.

Lastly, as a complementary study to our work in the endogenous model, we wanted to know if IVIg, SCIg or Fc- $\mu$ TP-L309C had any prophylactic activity. We used both the endogenous model and the serum transfer model to investigate this. For the endogenous model we 
treated mice with either IVIg, SCIg, or Fc- $\mu$ TP-L309C at weaning age before arthritis had developed. In both models, we found that both IVIg and SCIg prevented disease onset equally in these mice with the exception of a small rebound at the start of the treatment cycle in the serum transfer model. Fc- $\mu$ TP-L309C however, exhibited complete prevention without any rebound at the start of the treatment cycle.

\section{Conclusions}

In summary, we are the first group to show that $\mathrm{K} / \mathrm{BxN}$ mice, a model for human RA, having endogenous, chronic, severe arthritis can be effectively treated with IVIg, SCIg and with a recombinant protein, Fc- $\mu \mathrm{TP}-$ L309C. This model is a close representation of human autoimmune RA that is superior to the passive antibodyinduced serum-transfer model of arthritis, which models only the effector phase of arthritis and does not involve the adaptive immune system. Our work demonstrates the utility of using the $\mathrm{K} / \mathrm{BxN}$ mouse for evaluating potential therapeutic agents for treatment of RA. Although the efficacy of both IVIg and recombinant Fcs have yet to be confirmed in human studies, our results show that perhaps using higher doses and more frequent dosing in human RA could have benefit. Perhaps immunoglobulin-based therapies would show efficacy if used to treat certain subgroups of patients, or to treat patients with comorbidities that preclude them from using first line therapies, or to treat patients in whom other therapies are contraindicated. Importantly, the therapeutic effects of both IVIg and Fc- $\mu$ TP-L309C could be achieved with s.c. routes of administration. The s.c. administration of IgG products has become increasingly attractive in recent years due to patient convenience (home administration) and better systemic tolerability. Considering that lower doses are needed for Fc- $\mu$ TP-L309C to exhibit therapeutic efficacy in comparison to IVIg with the s.c. route of administration, Fc$\mu$ TP-L309C, given subcutaneously, could serve as a possible replacement therapy for IVIg/ SCIg in certain autoimmune diseases.

\section{Methods}

Mice

KRN T-cell receptor (TCR) transgenic mice on a C57BL/6J background were obtained from The Jackson Laboratory (Bar Harbor, ME), a kind gift from C. Benoist (Harvard Medical School, Boston, MA). NOD/LtJ mice were purchased from The Jackson Laboratory. Arthritic mice were obtained by crossing KRN mice (F, 6 weeks old) with NOD/Lt (M, 6 weeks old) mice to produce K/ BxN mice expressing both the TCR transgene KRN and the MHC class II molecule I-Ag7. BALB/cJ (F 6, weeks old) were purchased from The Jackson Laboratory (Bar
Harbor, ME). Mice were kept under a natural light-dark cycle, maintained at $22 \pm 4{ }^{\circ} \mathrm{C}$, and fed with standard diet and water ad libitum. The use of animals was consistent with the requirements of the CCAC - Canadian Council on Animal Care and the specific animal use protocol, AUP 1788.19, was reviewed and approved by the University Health Network (UHN) Animal Research Committee in Toronto. In general, 3 to 6 mice were used in each experimental and control group of animals. The numbers of animals used in each experiment can be found in the corresponding figure legends. To justify the minimum number of animals used for each experiment, we calculated the group size (n) required at $80 \%$ power and significance level (two-tailed, alpha $=0.05$ ) to observe an effect of the expected size using the $t$ statistic and non-centrality parameter (for comparing two means, effect size $\mathrm{E} / \mathrm{S}=\mathrm{k} * \delta$, where $t$ value at $\mathrm{df}=\mathrm{n}_{\text {total }}-2$, where $\mathrm{n}_{\text {total }}=\mathrm{n}_{1}+\mathrm{n}_{2}, \delta$ is the non-centrality parameter, and $\left.k=\left(1 / n_{1}+1 / n_{2}\right)^{1 / 2}\right)$. When the experiments were finished, mice were euthanized by cervical dislocation after $\mathrm{CO}_{2}$ inhalation.

\section{Biological reagents}

Privigen 10\% IVIg, Hizentra 20\% immunoglobulin (IgG) for subcutaneous use (SCIg), and Fc- $\mu$ TP-L309C, respectively, were from CSL Behring, Research, CSL Biologics Research Center (Bern, Switzerland). Human serum albumin (HSA) was from the Canadian Blood Services.

\section{$\mathrm{K} / \mathrm{BxN}$ serum transfer arthritis}

Severely arthritic adult $\mathrm{K} / \mathrm{BxN}$ mice were bled and the sera was pooled. BALB/cJ mice were injected intraperitoneally (i.p.) with $200 \mu \mathrm{l}$ of pooled sera on days 0 and 2 as indicated in the figure legends. The volume of sera was chosen based on in vivo titration of pooled sera. Mice were given treatment on day 2 with either an i.p. injection of $2 \mathrm{~g} / \mathrm{kg}$ of IVIg, a subcutaneous (s.c.) injection of $2 \mathrm{~g} / \mathrm{kg}$ of SCIg or a s.c. injection of $200 \mathrm{mg} / \mathrm{kg}$ of Fc$\mu \mathrm{TP}-\mathrm{L} 309 \mathrm{C}$ as indicated in the figure legends. HSA was used as a protein control.

\section{Arthritis prevention in the $\mathrm{K} / \mathrm{BxN}$ mouse model of endogenous, chronic arthritis}

$\mathrm{K} / \mathrm{BxN}$ mice, prior to onset of arthritis, at 21 days of age, were treated by i.p. injections of $2 \mathrm{~g} / \mathrm{kg}$ of IVIg or s.c. injections of $2 \mathrm{~g} / \mathrm{kg}$ of SCIg or s.c. injections of $200 \mathrm{mg} / \mathrm{kg}$ of Fc- $\mu$ TP-L309C. Treatments were given on days 1, 3, $5,7,11,13,15,17,19$, and 21 , as indicated in the figure legends. HSA was used as a protein control.

\section{Arthritis treatment in the $\mathrm{K} / \mathrm{BxN}$ mouse model of endogenous, chronic arthritis}

To investigate the ability of IVIg to ameliorate chronic arthritis, $\mathrm{K} / \mathrm{BxN}$ mice with high clinical scores of 9 or 
greater were treated by i.p. injections of either $1 \mathrm{~g} / \mathrm{kg}, 2$ $\mathrm{g} / \mathrm{kg}$, or $4 \mathrm{~g} / \mathrm{kg}$ of IVIg as indicated in the figure legends on days $1,3,5,7,9$, and 11 . The lowest dose of IVIg that showed efficacy was $2 \mathrm{~g} / \mathrm{kg}$ and this dose was selected to compare to SCIg while a titration of Fc- $\mu$ TP-L309C was performed using s.c. injections of Fc- $\mu$ TP-L309C at 200 $\mathrm{mg} / \mathrm{kg}, 100 \mathrm{mg} / \mathrm{kg}$, or $50 \mathrm{mg} / \mathrm{kg}$. Final comparisons were done using $2 \mathrm{~g} / \mathrm{kg}$ IVIg and SCIg and $200 \mathrm{mg} / \mathrm{kg} \mathrm{Fc-}$ $\mu$ TP-L309C. Treatments were administered on days 1,3 , $5,7,9$, and 11. HSA was used as a protein control.

\section{Arthritis scoring}

The clinical scores and the hind paw widths of the mice were monitored daily over the course of each experiment. The development of arthritis was assessed daily, and the severity of arthritis was scored for each paw on a 3 -point scale, in which $0=$ normal appearance, $1=$ localized edema/ erythema over one surface of the paw, 2 = edema/ erythema involving more than one surface of the paw, $3=$ marked edema/erythema involving the whole paw. The scores of all four paws were added for a composite score, with a maximum score of 12 per mouse. Ankle thickness of the hind paws was measured in millimeters $(\mathrm{mm})$ at the widest point (the malleoli) with the legs fully extended with digital calipers (Manostat, Herisau, Switzerland).

\section{Statistical analysis}

Statistical tests were performed using GraphPad Prism 8 for Windows software. Analyses of differences between sample groups were performed using the tests indicated in the figure legends. Data shown are mean \pm standard deviation (SD), unless otherwise stated. $P<0.05$ was considered statistically significant.

\begin{abstract}
Abbreviations
CIDP: Chronic inflammatory demyelinating neuropathy; FBS: Fetal bovine serum; FcRn: Neonatal Fc receptor; FcyR: Fc gamma receptor; Fc- $\mu T P-$ L309C: Recombinant IgG1 Fc hexamer; GVHD: Graft versus host disease; HSA: Human serum albumin; i.p.: Intraperitoneal; IgG: Immunoglobulingamma; ITP: Immune thrombocytopenia; IVIg: Intravenous immunoglobulin; MG: Myasthenia gravis; mm: Millimetre; RA: Rheumatoid arthritis; s.c.: Subcutaneous; SClg: Subcutaneous immunoglobulin; SD: Standard deviation; TCR: T-cell receptor
\end{abstract}

\section{Acknowledgements}

Not applicable.

\section{Author's contributions}

BJBL designed, performed, analyzed, and interpreted experiments and wrote the manuscript. JV, MB, and SC performed and analyzed experiments. RS, AWZ, and FK interpreted experiments and revised the manuscript. DRB designed and interpreted experiments and wrote the manuscript. All authors have read and approved the manuscript.

\section{Funding}

Partial funding for this study was provided by CSL Behring, CSL Biologics Research Center, Bern, Switzerland and CSL Behring Canada. FC- $\mu$ TP-L309C was provided IN KIND by CSL Behring, Research, CSL Biologics Research Center, Bern, Switzerland. BJBL is supported in part by a Canadian Blood Services
Graduate Fellowship Program (GFP) award. Research funding support was also provided by Canadian Blood Services through funding by the federal government (Health Canada) and the provincial and territorial ministries of health. The views herein do not necessarily reflect the views of the federal, provincial or territorial governments of Canada.

\section{Availability of data and materials}

All data generated or analyzed during this study are included in this published article.

\section{Ethics approval and consent to participate}

All experiments were conducted in compliance with the guidelines of CCAC - Canadian Council on Animal Care and approved by the University Health Network (UHN) Animal Research Committee in Toronto (Animal Use Permit (AUP) 1788.19).

\section{Consent for publication}

Not applicable.

\section{Competing interests}

The authors declare that RS, AWZ and FK are employees of CSL Behring, Research, CSL Biologics Research Center, Bern, Switzerland and that DRB received funding for the study from CSL Behring AG. There are no conflicts from remaining authors.

\section{Author details}

${ }^{1}$ Department of Laboratory Medicine and Pathobiology, University of Toronto, 67 College St., Toronto, Ontario M5G 2M1, Canada. ${ }^{2}$ Centre for Innovation, Canadian Blood Services, 67 College St., Toronto, Ontario M5G 2M1, Canada. ${ }^{3}$ School for Biology-Biochemistry-Biotechnology, Catholic University of Lyon, 10 place des Archives, 69288 Lyon Cedex 02, France. ${ }^{4}$ CSL Behring, Research, CSL Biologics Research Center, Wankdorfstrasse 10, 3010 Bern, Switzerland. ${ }^{5}$ Department of Medicine, University of Toronto, 67 College St., Toronto, Ontario M5G 2M1, Canada.

Received: 21 July 2019 Accepted: 21 November 2019

Published online: 04 December 2019

\section{References}

1. Ballow M. Primary immunodeficiency disorders: antibody deficiency. J Allergy Clin Immunol. 2002;109:581-91.

2. Buckley RH, Schiff RI. The use of intravenous immune globulin in immunodeficiency diseases. N Engl J Med. 1991;325:110-7.

3. Jolles S, Shapel H, Litzman J. When to initiate immunoglobulin replacement therapy (IGRT) in antibody deficiency: a practical approach. Clin Exp Immunol. 2017;188:333-41.

4. Bierling P, Godeau B. Intravenous immunoglobulin and autoimmune thrombocytopenic purpura 22 years on. Vox Sang. 2004;86:8-14.

5. Bussel J. The use of intravenous g-globulin in idiopathic thrombocytopenic purpura. Clin Immunol Immunopathol. 1989;53:S147-55.

6. Bussel J. Treatment of immune thrombocytopenic purpura in adults. Semin Hematol. 2006:43:S3-10, discussion S18-19.

7. Fehr J, Hofmann V, Kappeler U. Transient reversal of thrombocytopenia in idiopathic thrombocytopenic purpura by high-dose intravenous gamma globulin. N Engl J Med. 1982;306:1254-8.

8. Imbach P, Barandun S, d'Apuzzo V, Baumgartner C, Hirt A, Morell A, et al. High-dose intravenous gammaglobulin for idiopathic thrombocytopenic purpura in childhood. Lancet. 1989;1:1228-31.

9. Tarantino M. Recent advances in the treatment of childhood immune thrombocytopenic purpura. Semin Hematol. 2006;43:S11-S17, discussion S18-19.

10. Tackenberg B, Nimmerjahn F, Lunemann JD. Mechanisms of IVIG efficacy in chronic inflammatory demyelinating polyneuropathy. J Clin Immunol. 2010; (Suppl 1):S65-9.

11. Burns JC, Capparelli EV, Brown JA, Newburger JW, Glode MP. Intravenous gamma-globulin treatment and retreatment in Kawasaki disease. Pediatr Infect Dis J. 1998;17:1144-8.

12. Oates-Whitehead RM, Baumer JH, Haines L, Love S, Maconochie IK, Gupta A, et al. Intravenous immunoglobulin for the treatment of Kawasaki disease in children. Cochrane Database Syst Rev. 2003;4:CD004000. 
13. Alabdali M, Barnett C, Katzberg H, Breiner A, Bril V. Intravenous immunoglobulin as treatment for myasthenia gravis: current evidence and outcomes. Expert Rev Clin Immunol. 2014;10:1659-65.

14. Ballow $M$. The lgG molecule as a biological immune response modifier: mechanisms of action of intravenous immune serum globulin in autoimmune and inflammatory disorders. J Allergy Clin Immunol. 2011;127: 315-23.

15. Brandt D, Gershwin ME. Common variable immune deficiency and autoimmunity. Autoimmun Rev. 2006;5:465-70.

16. Etzioni F, Pollack S. High dose intravenous gammaglobulins in autoimmune disorders: mode of action and therapeutic uses. Autoimmun. 1989;3:307-15.

17. Kaveri SV, Dietrich G, Hurez V, Kazatchkine MD. Intravenous immunoglobulins (IVlg) in the treatment of autoimmune diseases. Clin Exp Immunol. 1991;86:192-8.

18. Nimmerjahn F, Ravetch JV. Anti-inflammatory actions of intravenous immunoglobulin. Annu Rev Immunol. 2008;26:513-33.

19. Prins C, Gelfand EW, French LE. Intravenous immunoglobulin: properties, mode of action and practical use in dermatology. Acta Derm Venereol. 2007;87:206-18.

20. Pyne $D$, Ehrenstein M, Morris V. The therapeutic uses of intravenous immunoglobulins in autoimmune rheumatic diseases. Rheumatol (Oxford) 2002;41:367-74

21. Stangel M, Hartung HP, Marx P, Gold R. Intravenous immunoglobulin treatment of neurological autoimmune diseases. J Neural Sci. 1998;153:203-14.

22. Nimmerjahn F, Ravetch JV. Fcgamma receptors as regulators of immune responses. Nat Rev Immunol. 2008:8:34-47.

23. Bussel JB. Fc receptor blockade and immune thrombocytopenic purpura. Semin Hematol. 2000;37:261-6.

24. Hansen RJ, Balthasar JP. Intravenous immunoglobulin mediates an increase in antiplatelet antibody clearance via the FcRn receptor. Thromb Haemost. 2002:88:898-9.

25. Li N, Zhao M, Hilario-Vargas J, Prisayanh P, Warren S, Diaz LA, et al. Complete FCRn dependence for intravenous lg therapy in autoimmune skin blistering diseases. J Clin Invest. 2005;115:3440-50.

26. De Groot AS, Moise L, McMurry JA, Wambre E, Van Overtvelt L, Moingeon $P$, et al. Activation of natural regulatory $T$ cells by lgG fc-derived peptide "Tregitopes". Blood. 2008;112:3303-11.

27. Samuelsson A, Towers TL, Ravetch JV. Anti-inflammatory activity of IVIG mediated through the inhibitory fc receptor. Sci. 2001;291:484-6.

28. Kapur R, Aslam R, Kim M, Guo L, Ni H, Segel GB, et al. Thymic-derived tolerizing dendritic cells are upregulated in the spleen upon treatment with intravenous immunoglobulin in a murine model of immune thrombocytopenia. Platelets. 2017;28:521-4.

29. Siragam V, Crow AR, Brinc D, Song S, Freedman J, Lazarus AH. Intravenous immunoglobulin ameliorates ITP via activating fc gamma receptors on dendritic cells. Nat Med. 2006;12:688-92.

30. Danieli MG, Gelardi C, Pedini V, Moretti R, Gabrielli A, Logullo F. Subcutaneous lgG in immune-mediate diseases: proposed mechanisms of action and literature review. Autoimmun Rev. 2014:1182-8.

31. Zuercher AW, Amsler L, Amstutz H, Andresen I, Bolli R, Hummel W, et al. Plasma-derived immunoglobulins. Princ Immunopharmacol. 2011:271-301.

32. Martin A, Lavoie L, Goetghebeur M, Schellenberg R. Economic benefits of subcutaneous rapid push versus intravenous immunoglobulin infusion therapy in adult patients with primary immune deficiency. Transfus Med. 2013;23:55-60

33. Jain A, Olsen HS, Vyzasatya R, Burch E, Sakoda Y, Merigeon EY. Fully recombinant lgG2a fc multimers (stradomers ${ }^{T M}$ ) effectively treat collagen induced arthritis and prevent idiopathic thrombocytopenic purpura in mice. Arthritis Res Ther. 2012;14:R192.

34. Mekhaiel DNA, Czajkowsky DM, Andersen JT, Shi J, El-Faham M, Doenhoff $M$, et al. Polymeric human fc-fusion proteins with modified effector functions. Sci Rep. 2011;124.

35. Niknami M, Wang MX, Nguyen T, Pollard JD. Beneficial effect of a multimerized immunoglobulin $\mathrm{fc}$ in an animal model of inflammatory neuropathy (experimental autoimmune neuritis). J Peripher Nerv Syst. 2013; 8:141-52.

36. Ortiz DF, Lansing JC, Rutitzky L, Kurtagic E, Prod'homme T, Choudhury A, et al. Elucidating the interplay between lgG-Fc valency and FcyR activatin for the design of immune complex inhibitors. Sci Transl Med. 2016;8: 365 ra158.
37. Qureshi OS, Rowley TF, Junker F. Multivalent Fcy-receptor engagement by a hexameric fc-fusion protein triggers Fcy-receptor internalisation and modulation of Fcy-receptor functions. Sci Rep. 2017;7:17049.

38. Spirig R, Campbell IK, Koernig S, Chen CG, Lewis BJB, Butcher R, et al. rlgG1 fc Hexamer inhibits antibody-mediated autoimmune disease via effects on complement and FcyRs. J Immunol. 2018;200(8):2542-53.

39. Thiruppathi M, Sheng JR, Li L, Prabhakar BS, Meriggioli MN. Recombinant lgG2a fc (M045) multimers effectively suppress experimental autoimmune myasthenia gravis. J Autoimmun. 2014;52:64-73.

40. Washburn N, Schwab I, Ortiz D, Bhatnagar N, Lansing JC, Medeiros A, et al. Controlled tetra-fc sialyation of IVlg results in a drug candidate with consistent enhanced anti-inflammatory activity. Proc Natl Acad Sci U S A. 2015;112:E1297-306.

41. Zhou H, Olsen H, So E. A fully recombinant human IgG1 fc multimer (GL2045) inhibits complement-mediated cytotoxicity and induces iC3b. Blood Adv. 2017;1:504-15.

42. Kanik KS, Yarboro CH, Naparstek Y, Plotz PH, Wilder RL. Failure of lowdose intravenous immunoglobulin therapy to suppress disease activity in patients with treatment-refractory rheumatoid arthritis. Arthritis Rheum. 1996;39:1027-9.

43. Maksymowych WP, Aviña-Zubieta A, Luong M, Russell AS. High dose intravenous immunoglobulin (IVlg) in severe refractory rheumatoid arthritis: no evidence for efficacy. Clin Exp Rheumatol. 1996;14:657-60.

44. Muscat C, Bertotto A, Ercolani R. Long term treatment of rheumatoid arthritis with high doses of intravenous immunoglobulins: effects on disease activity and serum cytokines. Ann Rheum Dis. 1995;54:382-5.

45. Prieur AM, Adleff A, Debre M, Boulate P, Griscelli C. High dose immunoglobulin therapy in severe juvenile chronic arthritis: long-term follow-up in 16 patients. Clin Exp Rheumatol. 1990;8:603-8.

46. Tumiati B, Casoli P, Veneziani M, Rinaldi G. High-dose immunoglobulin therapy as an immunomodulatory treatment of rheumatoid arthritis. Arthritis Rheum. 1992;35:1126-33.

47. Vaitla PM, McDermott EM. The role of high-dose intravenous immunoglobulin in rheumatology. Rheumatol. 2010:49:1040-8.

48. Anthony RM, Nimmerjahn F, Ashline DJ, Reinhold VN, Paulson JC, Ravetch JV. Recapitulation of IVIG anti-inflammatory activity with a recombinant IgG fc. Sci. 2008;320:373-6.

49. Anthony RM, WermelingF KMC, Ravetch JV. Identification of a receptor required for the anti-inflammatory activity of IVIG. Proc Natl Acad Sci USA. 2008;105:19571-8

50. Campbell IK, Miescher S, Branch DR, Mott PJ, Lazarus AH, Han D. Therapeutic effect of IVIG on inflammatory arthritis in mice is dependent on the fc portion and independent of sialylation or basophils. J Immunol. 2014; 192:5031-8

51. Kaneko Y, Nimmerjahn F, Ravetch JV. Anti-inflammatory activity of immunoglobulin G resulting from fc sialyalation. Sci. 2006;313:670-3.

52. Ditzel HJ. The K/BxN mouse: a model of human inflammatory arthritis Trends Mol Med. 2004;10:40-5.

53. Korganow AS, Ji H, Mangialaio S, Duchatelle V, Pelanda R, Martin T, et al. From systemic $T$ cell self-reactivity to organ-specific autoimmune disease via immunoglobulins. Immun. 1999:10:451-61.

54. Mangialaio S, Ji H, Korganow AS, Kouskoff VR, Benoist C, Mathis D. The arthritogenic $T$ cell receptor and its ligand in a model of spontaneous arthritis. Arthritis Rheum. 1999;42:2517-23.

55. Matsumoto I, Staub A, Benoist C, Mathis D. Arthritis provoked by linked T and B cell recognition of a glycolytic enzyme. Sci. 1999;286:1732-5.

56. Christensen AD, Haase C, Cook AD, Hamilton JA. K/BxN serum-transfer arthritis as a model for human inflammatory arthritis. Front Immunol. 2016;7:213.

57. Monach PA, Hattori $\mathrm{K}$, Huang $\mathrm{H}$, Hyatt E, Morse J, Nguyen L, et al. The $\mathrm{K}$ BxN mouse model of inflammatory arthritis. Arthritis Res. 2007:269-82.

58. Monach PA, Mathis D, Benoist C. The K/BxN Arthritis Model. Curr Protoc Immunol. 2008;15:Unit 15.22.

59. Sewell WAC, Jolles S. Immunomodulatory action of intravenous immunoglobulin. Immunol. 2002;107:387-93.

60. Brand DD, Latham KA, Rosloniec EF. Collagen-induced arthritis. Nat Protoc. 2007;2:1269-75

61. Khachigian LM. Collagen antibody-induced arthritis. Nat Protoc. 2006;1: 2512-6.

62. Lee SY, Jung YO, Ryu JG, Kang CM, Kim EK, Son HJ, et al. Intravenous immunoglobulin attenuates experimental autoimmune arthritis by inducing 
reciprocal regulation of Th17 and Treg cells in an interleukin-10-dependent manner. Arthritis Rheumatol. 2014;66:1768-78.

63. Ohmi Y, Ise W, Harazono A, Takakura D, Fukuyama H, Baba Y, et al.

Sialylation converts arthritogenic lgG into inhibitors of collagen-induced arthritis. Nat Commun. 2016;7:11025.

64. Richter WF, Jacobsen B. Subcutaneous absorption of biotherapeutics: knowns and unknowns. Drug Metab Dispos. 2014;42:1881-9.

\section{Publisher's Note}

Springer Nature remains neutral with regard to jurisdictional claims in published maps and institutional affiliations.

Ready to submit your research? Choose BMC and benefit from:

- fast, convenient online submission

- thorough peer review by experienced researchers in your field

- rapid publication on acceptance

- support for research data, including large and complex data types

- gold Open Access which fosters wider collaboration and increased citations

- maximum visibility for your research: over $100 \mathrm{M}$ website views per year

At $\mathrm{BMC}$, research is always in progress.

Learn more biomedcentral.com/submissions 